\title{
Oil price volatility and its impact on economic growth and food security in Bangladesh
}

\author{
Mousumi Saha $^{1}$, Seikh Mohammad Sayem ${ }^{1},{ }^{\bowtie}$ A. K. M. Abdullah Al-Amin ${ }^{2}$ and Shankar Majumder ${ }^{1}$ \\ ${ }^{1}$ Department of Agricultural Statistics, Bangladesh Agricultural University, Mymensingh-2202, Bangladesh \\ ${ }^{2}$ Department of Agricultural Economics, Bangladesh Agricultural University, Mymensingh-2202, Bangladesh
}

\begin{tabular}{|c|c|}
\hline ARTICLE INFO оPEN ${ }^{\text {access }}$ & Abstract \\
\hline $\begin{array}{l}\text { Article history: } \\
\text { Received: } 27 \text { May } 2018 \\
\text { Accepted: } 21 \text { October } 2018 \\
\text { Published: } 31 \text { December } 2018 \\
\text { Keywords: } \\
\text { Economic growth; Econometric } \\
\text { modeling; Food security; Oil } \\
\text { price volatility }\end{array}$ & $\begin{array}{l}\text { This study empirically examines oil price volatility and the impact of oil price changes on the growth of } \\
\text { the economy and food security in Bangladesh. The study uses yearly data of macroeconomic variables } \\
\text { from } 1991 \text { to } 2015 \text { and global food security index (GFSI) for the period } 2012 \text { to } 2015 \text {. Furthermore, data } \\
\text { of GFSI for previous four years have been simulated using exponential model. The GARCH }(2,1) \text { model } \\
\text { with minimum AIC postulates that volatility was high in the previous period and it has been continued to } \\
\text { be lower in the current period (i.e. 2015). The co-integration test and error correction model exhibit that } \\
\text { both in short-run and long-run case the increasing oil price negatively affected the growth of the economy. } \\
\text { The simultaneous equations regression model using three-stage least squares estimator discloses that an }\end{array}$ \\
\hline $\begin{array}{l}\text { Correspondence: } \\
\text { A. K. M. Abdullah Al-Amin } \\
\text { 凶: abdullah.alamin@bau.edu.bd }\end{array}$ & $\begin{array}{l}\text { increase in oil price declines the economic growth and food security simultaneously and significantly. } \\
\text { Moreover, this study suggests that oil price volatility is not a good sign for the economy of Bangladesh, } \\
\text { since, the country is an importer of crude oil, government policy should be quick responsive in relation to } \\
\text { international oil market to create consistent oil market and sustainable economic development in } \\
\text { Bangladesh. }\end{array}$ \\
\hline
\end{tabular}

Copyright:

(c) (i)

(O2018 by authors and BAURES. This work is licensed under the Creative Commons Attribution International License (CC By 4.0).

\section{Introduction}

Crude oil is one of the most imperative driving forces of the global economy and any changes in the price of oil has significant effects on the growth of the economy, food security and welfare around the world. Economists with their empirical analysis of different economies have examined that oil price volatility is a significant determinant of the economic growth (Mork, 1989; Lee et al., 1995; Hamilton, 2003; Akram, 2011; and Srithar et al., 2015) and food security (Ciaian and Kancs, 2011; Bakhat and Wurzburg, 2013; Hao et al., 2013; and Dillon and Barrett, 2015). Being most widely used energy resource it accounts for approximately $40 \%$ of the global energy demand and its consumption is over 85 million barrels per day (Srithar et al., 2015).

There are three oil markets existing in the world, these are: the European Brent, the WTI (West Texas Intermediate) and the OPEC (Organization of Petroleum Exporting Countries). Bangladesh is under least developed countries and not an oil producing country. Furthermore, being one of the non-OPEC countries, it fulfills its domestic demand by the way of import. So any trivial fluctuation in the oil prices can have both direct and indirect influence on the economy. Most of the prior studies pertaining to oil price volatility and economic activities have been conducted in the context of developed economies (e.g., Burbridge and Harrison, 1984; Gisser and Goodwin, 1986; Mork and Olsen,
1994; and Ferderer, 1996). Research related to the impact of oil price unpredictability in the context of developing countries is very scant because of partly lack of reliable data and less historical dependence of these countries on oil. This especially holds true in case of Bangladesh, since the realm has entered into the open market in 1991. Therefore, the present study primarily focuses on the oil price volatility and its impact on the growth of the economy as the economic growth is the increase in the inflation-adjusted market value of the goods and services produced by an economy over time. It is conventionally measured as the percent rate of increase in real gross domestic product, or real GDP (Mgbame et al., 2015). In this study, the real gross domestic product (RGDP) has been used to measure the economic growth. Measurement of economic growth of a country is a complex issue. It comprises of different contributing channels and factors. Economic literature (Romer, 2006) emphasizes that output is mainly a function of capital and effective labor. In order to show the long-run and short-run relationship, the variables such as Import Oil Price (OP), Real Gross Domestic Product (RGDP), Gross Capital Formation (GCF) and Labor Force Participation Rate (LFPR) have been taken in this study. Here, Gross capital formation (formerly gross domestic investment) consists of fixed assets of the economy plus net changes in the level of inventories and labor force participation rate (LFPR) is the proportion of the population ages 15 and older that is 
economically active: all people who supply labor for the production of goods and services during a specified period.

As the economic growth in Bangladesh is highly dependent on food production, the ultimate objective of our study is to know how the oil price changes influence on food security. According to Torero (2014) economic growth is only sustainable if all countries try to achieve food security as a base for their citizens. There will be impediments and marginal costs to global, regional and country level economic growth without a country-owned and country-driven food security strategy. Since the current national food system in Bangladesh is highly fuel and transport dependent, higher oil prices may reduce economic growth which eventually leads to pecuniary and financial instability and ultimately it brings obstacles to gain food security. In our study, we take Global Food Security Index (GFSI) as an indicator of food security status as GFSI examines food security comprehensively across the three internationally established dimensions (i.e., affordability, availability, and quality).

A general assumption is that, consumer price index (CPI) affects market prices and this in turn influences household purchasing power thus exposing the household to food insecurity. On the other hand, GDP and CPI directly affect each other. According to investopedia.com, the CPI indicates whether the economy is experiencing inflation, deflation or stagflation. In an international context, oil prices may have a different impact on each of the countries such as the sector base composition, tax structure and regulations or the country's position as oil net importer or exporter. For instance, some studies suggest that the impact of oil price is only limited to the short-run (Cunado and Gracia, 2005) while the others suggest both long-run and short-run relations (Rautava, 2004). Keeping in view of these reports about significant impacts of crude oil price on economic growth and food security for developing countries, it would be interesting to know the situation in the perspective of Bangladesh. Being an oil importing country, an increase of world oil price would increase the production costs of the country that retard its economic growth and food security, for that reason, our study endeavours to incorporate economist's perceptions through the primary survey for rigorous policy guidelines to ensure consistent oil market. Moreover, our findings may help to answer various questions which are still far from consensus in the literature.

\section{Materials and Methods}

\section{Data}

The secondary data have been collected from Bangladesh Economic Review (BER), World Bank (WB), Food and Agriculture Organization (FAO) and Inflation Data.com. The data on international crude oil price, import crude oil price, Real Gross Domestic
Product (RGDP), Gross Capital Formation (GCF), Labor Force Participation Rate (LFPR), Exchange Rate (ER) and Consumer Price Index (CPI) have been taken from 1991 to 2015 whereas the value Global food security index (GFSI) has been taken for the period 2012 to 2016. Again, the data of GFSI on previous four years (2008-2011) have been simulated through an exponential model. The primary data have also been collected from economic specialists using questionnaire survey for finding out the reasons behind oil price volatility and taking appropriate suggestions to reduce possible negative effects on economic growth and food security.

\section{Model Specification}

\section{Generalized Autoregressive Conditional Heterosce- dasticity (GARCH) model}

Correlogram and different unit root tests especially the Augmented Dickey-Fuller (ADF) and Phillips-Perron (PP) test have been adopted to test the stationarity of international oil price and import oil price. Hence, the GARCH model has been applied to measure the volatility of both international oil price and import oil price. The reasons of using GARCH model are: (i) forecast confidence intervals may be time-varying, so more accurate intervals can be obtained by modeling the variance of the errors and (ii) more efficient estimators can be obtained, if heteroscedasticity in the errors is handled properly. The GARCH (u, v) models for the international oil price is-

$$
\begin{aligned}
& \operatorname{INOP}_{t}=\alpha_{0}+\sum_{i=1}^{p} \alpha_{i} \operatorname{INOP}_{t-i}+u_{t} \\
& { }^{\sigma} \mathrm{INOP}_{\mathrm{t}}^{2}=\tau+\sum_{\mathrm{m}=1}^{\mathrm{u}} \theta_{\mathrm{m}} \mathrm{u}_{\mathrm{t}-\mathrm{m}}^{2}+\sum_{\mathrm{n}=1}^{\mathrm{v}} \mu_{\mathrm{n}}{ }^{\sigma} \mathrm{INOP}_{\mathrm{t}-\mathrm{n}}^{2}
\end{aligned}
$$

Again, the GARCH (x, y) models for the import oil price is -

$$
\begin{aligned}
& \operatorname{IMOP}_{t}=\beta_{0}+\sum_{j=1}^{q} \beta_{j} \operatorname{IMOP}_{t-j}+v_{t} \\
& { }^{\mathrm{x}} \mathrm{IMOP}_{\mathrm{t}}^{2}=\varphi+\sum_{\mathrm{r}=1}^{\mathrm{x}} \gamma_{\mathrm{r}} \mathrm{v}_{\mathrm{t}-\mathrm{r}}^{2}+\sum_{\mathrm{s}=1}^{\mathrm{y}} \delta_{\mathrm{s}}{ }^{\sigma} \mathrm{IMOP}_{\mathrm{t}-\mathrm{s}}^{2}
\end{aligned}
$$

${ }^{\sigma} \mathrm{INOP}_{\mathrm{t}}^{2}$ and ${ }^{\sigma} \mathrm{IMOP}_{\mathrm{t}}^{2}$ are the one-period ahead forecast conditional variance based on past information. The conditional variance equation specified in these equations ( 1 and 2$)$ is a function of three terms: constant term $(\tau, \varphi)$, the ARCH term refers the lag of the squared residual $\left(\sum_{m=1}^{u} u_{t-m}^{2}, \sum_{r=1}^{x} v_{t-r}^{2}\right)$ and lastly, the GARCH 
term refers the lagged conditional variances $\left(\sum_{\mathrm{n}=1}^{\mathrm{v}}{ }^{\sigma} \mathrm{INOP}_{\mathrm{t}-\mathrm{n}}, \sum_{\mathrm{s}=1}^{\mathrm{y}}{ }^{\sigma} \mathrm{IMOP}_{\mathrm{t}-\mathrm{s}}^{2}\right)$ (Bollerslev, 1986).

Vector Autoregression (VAR) modeling and Johansen co-integration procedure

The Johansen co-integration procedure is the extension of univariate Dickey-Fuller test to multivariate VAR framework. The estimation strategy is as follows: Firstly, the stationarity in each variable has been checked. Secondly, a Johansen co-integration test among the variables has been done to check whether a long run relation exists among the series. And finally, the shortrun dynamic behaviour among OP, GCF, LFPR and RGDP has been studied by error correction model.

For co-integration test the model can be stated as follows:

$\ln R G D P=\beta_{0}+\beta_{1} \ln O P+\beta_{2} \ln G C F+\beta_{3} \ln L F P R+\varepsilon_{t}$

Where $\operatorname{lnRGDP}=\log$ of real gross domestic product, $\operatorname{lnOP}=\log$ of import oil price, $\operatorname{lnGCF}=\log$ of gross capital formation, $\operatorname{lnLFPR}=\log$ of labor force participation rate, $\varepsilon_{t}=$ Error term. All of the variables have been log-transformed to achieve the normality assumption. The null hypothesis of no cointegration is rejected if it is found that the regression residuals are stationary at level.

VAR modeling: Let $Y_{t}$ follows p-order autoregressive process:

$Y_{t}=B_{1} Y_{t-1}+B_{2} Y_{t-2}+\ldots .+B_{p} Y_{t-p}+U_{t}$

where $Y_{t}$ is an $(4 \times 1)$ vector of $\operatorname{lnRGDP}, \operatorname{lnOP}, \operatorname{lnGCF}$ and $\operatorname{lnLFPR}$. Equation (4) is transformed into a more appropriate form for statistical testing. First subtract $\mathrm{Y}_{\mathrm{t}-1}$ from both sides of (4) to yield:

$\Delta Y_{t}=\left(B_{1}-1\right) Y_{t-1}+B_{2} Y_{t-2}+B_{3} Y_{t-3}+\ldots . B_{p} Y_{t-p}+U_{t}$

Then add and subtract $\left(B_{1}-1\right) Y_{t-2}$ on the right-hand side of the above equation to obtain:

$\Delta Y_{t}=\left(B_{1}-1\right) \Delta Y_{t-1}+B_{2} Y_{t-2}+B_{3} Y_{t-3}+\ldots . B_{p} Y_{t-p}+U_{t}$

Next add and subtract $\left(\mathrm{B}_{1}+\mathrm{B}_{2}-1\right) \mathrm{Y}_{\mathrm{t}-3}$ to arrive at

$\Delta Y_{t}=\left(B_{1}-1\right) \Delta Y_{t-1}+\left(B_{1}+B_{2}-1\right) \Delta Y_{t-2}+\left(B_{1}+B_{2}+B_{3}-1\right) Y_{t-3}+\ldots$

$+B_{p} Y_{t-p}+U_{t}$

A similar process is repeated until eventually equation (4) is obtained:

$\Delta Y_{t}=\sum_{i=1}^{p-1} \phi_{i} \Delta Y_{t-i}+\phi Y_{t-p}+U_{t}$

where $\phi_{i}=-\left(1-B_{1}-B_{2}-\ldots . .-B_{i}\right)$ and

$\phi=-\left(1-B_{1}-B_{2}-\ldots . .-B_{p}\right)$

Equation (5) is known as a vector error correction model (VECM) and the error correction is embodied in $\phi Y_{t-p}$.

The parameter matrices $\phi_{i}$ and $\phi$ in equation (5) are short-run and long-run adjustments to the changes in $Y_{t}$, respectively. The matrix $\phi$ can be expressed as a product of two matrices:

$\phi=\alpha \beta^{\prime}$

where $\alpha$ represents the speed of adjustment to disequilibrium and $\beta$ is a matrix of long-run coefficients such that the term $\beta^{\prime} Y_{t-p}$ represents $r \leq(4-1)$ cointegration vectors which ensures that $Y_{t}$, converges to its long-run equilibrium status.

The number of co-integrating vector can be obtained by looking at the significance of characteristic roots of $\phi$. Hence, the number of characteristic roots can be calculated from the following statistics:

$$
\begin{aligned}
& \lambda_{\text {trace }}=-T \sum_{i=r+1}^{m} \ln \left(1-\hat{\lambda}_{i}\right) \\
& \lambda_{\text {max }}=-T \ln \left(1-\hat{\lambda}_{r+1}\right)
\end{aligned}
$$

where $\hat{\lambda}_{i}$ the estimated values of the characteristic roots from the estimated $\phi$ matrix in equation (5) and $\mathrm{T}$ is the total number of observations. The first test is known as trace test. The null hypothesis is that there are at most $r$ co-integrating vectors, where, the alternative hypothesis refers that there are more than $\mathrm{r}$ co-integrating vectors. The second statistic, known as the maximal eigen value test, assumes that the rank is $r$ against the alternative that the rank is $(r+1)$. Johansen and Juselius (1990) report the critical values for these two statistics based on a Monte Carlo simulation approach.

\section{Simultaneous equations regression model}

Since global food security index (GFSI) is a multidimensional aspect, a change in oil price may not have the direct impact on it. Firstly, Granger causality test has been adopted to find out the nature of causality among OP, RGDP, CPI, and GFSI. Then, simultaneous equations regression model has been used to show the relationship between import oil price and food security as simultaneous equations model is used rather than classical linear regression model when the error term is correlated with explanatory variable. Again, if the OLS estimator is used in this situation, it will provide biased and inconsistent estimates of the population parameters. So, the simultaneous equations regression model is -

$$
\ln R G D P=\alpha_{0}+\alpha_{1} \ln G F S I+\alpha_{2} \ln O P+u_{1 t}
$$

$$
\ln G F S I=\beta_{0}+\beta_{1} \ln R G D P+\beta_{2} \ln C P I+u_{2 t}
$$

where, $u_{1 t}$ and $u_{2 t}$ are the stochastic disturbance terms and $\alpha_{0}, \alpha_{1}, \beta_{0}, \beta_{1}$ and $\beta_{2}$ are unknown parameters. lnGFSI and lnRGDP are endogenous variables. Equation 
(8) excludes exactly one variable $\ln C P I$ and equation

(9) excludes exactly one variable $\ln O P$. Hence each equation is identified by order condition. Therefore, the model as a whole is identified. This model has been estimated using three-stage least squares (3SLS) estimator because this estimator is used to estimate two or more identified equations in a simultaneous equation model together.

The three-stage least squares (3SLS) estimator involves the following three stage procedure.

1. Regress each right-hand side endogenous variable in the equation to be estimated on all exogenous variables in the simultaneous equation model using the OLS estimator. Calculate the fitted values for each of these endogenous variables.

2. In the equation to be estimated, replace each endogenous right-hand side variable by its fitted value variable. Estimate the equation using the OLS estimator.

3. Apply the seemingly unrelated regression (SUR) estimator.

\section{Empirical Results}

\section{Evaluation of oil price volatility}

The empirical work based on time series data assumes that the time series is stationary. To envisage the basic pattern of the data, the time series plot of both import and the international oil price has been constructed. From Fig. 1, it is evident that both series of oil price present upward trend, exposing that the mean of both international oil price and import oil price have been changing. This extent of the fluctuation with time is known as non-stationary.
In Fig. 2 and Fig. 3, the correlograms of both international oil price and import oil price have been shown and the correlograms have been exhibited a similar pattern. At lag 1, the autocorrelation coefficients for the international oil price and that for the import oil price are a very high value $(0.864$ and 0.905 respectively). In both cases, the slowly declining trends reveal that the time series are non-stationary. So, time series of both international market oil price and import oil price must be $1^{\text {st }}$ differenced to see if the $1^{\text {st }}$ differenced time series are stationary or not. Fig. 4 and Figure 5 exhibit much different pattern of ACF and PACF. All the spikes of ACF and PACF for international oil price and import oil price are inside the 95\% confidence bounds. Therefore, the correlogram test results also indicate that there is a unit root for both time series in their levels and they are stationary in their first differences.

The outcome from Table 1 also shows that the first difference of both international oil price and import oil price have no unit root because the first difference of both prices have a unit root has been rejected, as the calculated value of Augmented Dickey-Fuller and Phillips-Perron t-statistics are greater than the critical value of Augmented Dickey-Fuller t-statistics. Therefore, it may be concluded that the first difference of both international oil price and import oil price at a level are non-stationary. Table 1 also indicates that the time series of both international oil price and import oil price have a unit root and is stationary in their first differences.

Table 1. Unit root test for international oil price and import oil price

\begin{tabular}{lcccccc}
\hline \multirow{2}{*}{ Items } & Difference & \multicolumn{2}{c}{ Augmented Dickey Fuller Test } & \multicolumn{2}{c}{ Phillips-Perron Test } & \multirow{2}{*}{ Comment } \\
\cline { 3 - 6 } & & t-statistic & p-value & t-statistic & p-value & \\
\hline International & Level & -2.661 & 0.259 & -2.552 & 0.303 & $1^{\text {st }}$ differenced \\
oil price & $1^{\text {st }}$ difference & -5.237 & 0.002 & -13.446 & 0.000 & stationary \\
Import oil & Level & -2.260 & 0.438 & -2.279 & 0.428 & $1^{\text {st }}$ differenced \\
price & $1^{\text {st }}$ difference & -3.708 & 0.042 & -3.625 & 0.049 & stationary \\
\hline
\end{tabular}

From the stationarity test, it has been found that international oil price and import oil price are nonstationary time series and in the first difference form they are stationary. But it is difficult to model the first differences of these two time series because heteroscedasticity over the different period has been auto correlated. This is wherever the Autoregressive Conditional Heteroscedasticity (ARCH) model, which is developed by Engle (1982).

GARCH model results have been given in Appendix. By referring Table 2, as the GARCH $(2,1)$ model for the international oil price and the import oil price have minimum AIC, these models are appropriate for both cases. In these models (see Appendix) lagged error variances are statistically significant, so there is GARCH effect in both cases, that is, volatility in the current period is related to the previous period. On the other hand, the coefficient of GARCH term is negative in both time series; it suggests that volatility of both international oil price and import oil price were high in the previous periods and in the current period it has been continued to be low.

\section{Table 2. Results of GARCH model}

\begin{tabular}{cccc}
\hline \multicolumn{2}{c}{ International oil price } & \multicolumn{2}{c}{ Import oil price } \\
\hline Model & AIC & Model & AIC \\
GARCH $(1,1)$ & 22.98473 & GARCH $(1,1)$ & 23.27583 \\
GARCH(1,2) & 22.99640 & GARCH(1,2) & 23.24082 \\
GARCH(2,1) & 22.76377 & GARCH(2,1) & 23.14643 \\
GARCH(2,2) & 22.87426 & GARCH(2,2) & 23.15047 \\
\hline
\end{tabular}


Saha et al.

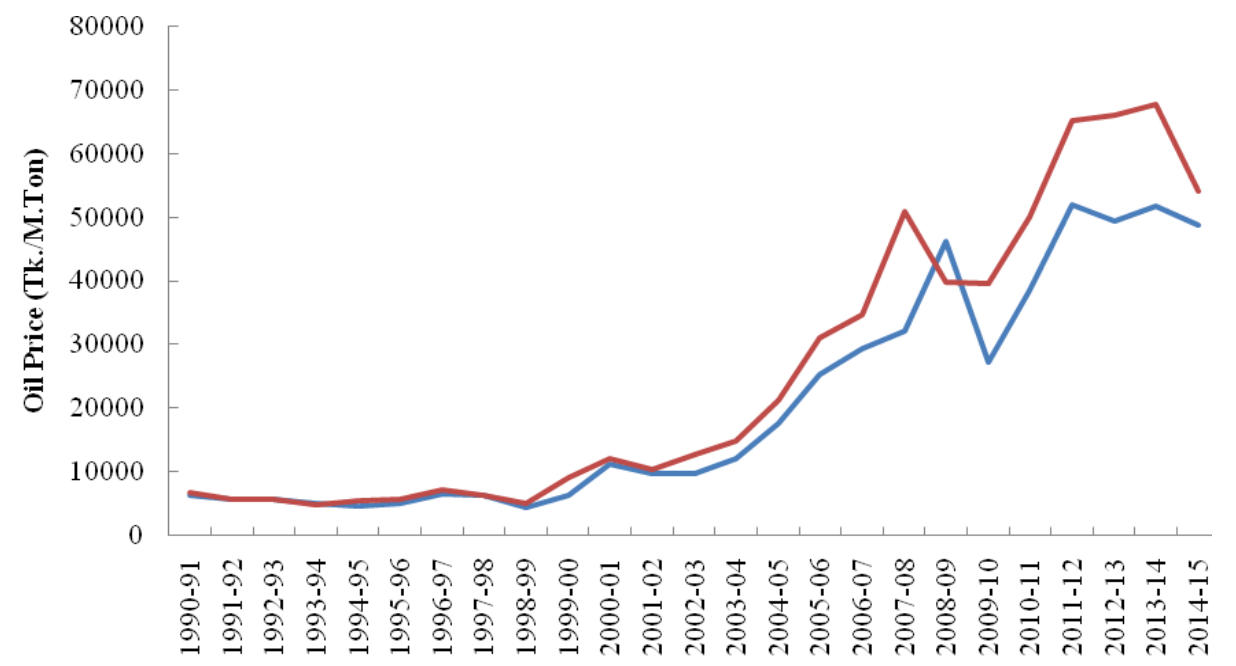

Financial Year

—International Oil Price(Tk./M.Ton) —Import Oil Price (Tk./M.Ton)

Fig. 1. Time series plot of import oil price and international oil price during 1990-91 to 2014-2015

Sample: 125

Included observations: 25

\begin{tabular}{|c|c|c|c|c|c|c|c|}
\hline \multicolumn{2}{|c|}{ Autocorrelation } & \multicolumn{2}{|c|}{ Partial Correlation } & $A C$ & PAC & Q-Stat & Prob \\
\hline 1 & 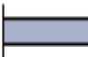 & 1 & 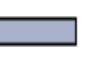 & 10.864 & 0.864 & 20.993 & 0.000 \\
\hline 1 & & 1 & 1 & 20.748 & 0.005 & 37.403 & 0.000 \\
\hline & $\square$ & । & 1 & 30.646 & -0.006 & 50.195 & 0.000 \\
\hline & $\square$ & 1마 & । & 40.490 & -0.267 & 57.909 & 0.000 \\
\hline & $\square$ & 1 & 1 & $\begin{array}{ll}5 & 0.392\end{array}$ & 0.112 & 63.084 & 0.000 \\
\hline । & $\square$ & 1 & 1 & $\begin{array}{ll}6 & 0.312\end{array}$ & 0.007 & 66.545 & 0.000 \\
\hline 1 & 71 & $\square$ & । & 70.152 & -0.342 & 67.417 & 0.000 \\
\hline 1 & 1 & 10 & 1 & 80.035 & -0.041 & 67.467 & 0.000 \\
\hline
\end{tabular}

Fig. 2. Correlogram and partial Correlogram for international crude oil price

Sample: 125

Included observations: 25

\begin{tabular}{|c|c|c|c|c|c|c|c|}
\hline \multicolumn{2}{|c|}{ Autocorrelation } & \multicolumn{2}{|c|}{ Partial Correlation } & $A C$ & PAC & Q-Stat & Prob \\
\hline 1 & . & 1 & - & 10.903 & 0.905 & 23.043 & 0.000 \\
\hline 1 & & $1 \square$ & 1 & 20.764 & -0.306 & 40.172 & 0.000 \\
\hline 1 & $\square$ & 1 & 1 & 30.621 & -0.028 & 52.021 & 0.000 \\
\hline 1 & $\square$ & 1 & 1 & 40.493 & -0.016 & 59.825 & 0.000 \\
\hline 1 & $\square$ & 1 & 1 & 50.392 & 0.048 & 65.012 & 0.000 \\
\hline 1 & $\square$ & 10 & 1 & 60.299 & -0.097 & 68.180 & 0.000 \\
\hline 1 & $\square 1$ & $1 \square$ & 1 & 70.174 & -0.265 & 69.320 & 0.000 \\
\hline 1 & 1 & 10 & 1 & $\begin{array}{ll}80.024 \\
\end{array}$ & -0.175 & 69.344 & 0.000 \\
\hline
\end{tabular}

Fig. 3. Correlogram and partial Correlogram for import crude oil price
Sample: 125

Included observations: 24

\begin{tabular}{|c|c|c|c|c|c|c|c|}
\hline \multicolumn{2}{|c|}{ Autocorrelation } & \multicolumn{2}{|c|}{ Partial Correlation } & $A C$ & PAC & Q-Stat & Prob \\
\hline $1 \square$ & I & $\mid$ & 1 & $1-0.334$ & -0.334 & 3.0329 & 0.082 \\
\hline 10 & 1 & 15 & 1 & $2-0.130$ & -0.272 & 3.5117 & 0.173 \\
\hline 1 & 1 & 10 & 1 & 30.232 & 0.104 & 5.1135 & 0.164 \\
\hline 1 & 1 & 1 & 1 & $4-0.135$ & -0.046 & 5.6826 & 0.224 \\
\hline 1 & I & 1 & 1 & $\begin{array}{ll}5 & 0.135\end{array}$ & 0.164 & · 6.2846 & 0.280 \\
\hline 1 & I & I & 1 & 60.001 & 0.060 & 6.2846 & 0.392 \\
\hline 1 & 1 & 1 & 1 & 70.004 & 0.116 & 6.2851 & 0.507 \\
\hline 1 & 1 & 1 & 1 & 80.053 & 0.057 & 6.3944 & 0.603 \\
\hline
\end{tabular}

Fig. 4. Correlogram and partial Correlogram for $1^{\text {st }}$ differences of international crude oil price

Sample: 125

Included observations: 24

\begin{tabular}{|c|c|c|c|}
\hline Autocorrelation & Partial Correlation & $P A C$ & Q-Stat Prob \\
\hline 11 & 1 & 10.0180 .018 & 0.00910 .924 \\
\hline 11 & 1 & $2-0.060-0.061$ & $0.1120 \quad 0.946$ \\
\hline 1口। & । & $3-0.281-0.280$ & $2.4561 \quad 0.483$ \\
\hline 11 & 11 & $40.007 \quad 0.010$ & $2.4576 \quad 0.652$ \\
\hline 171 & 171 & $\begin{array}{lll}5 & 0.127 & 0.103\end{array}$ & 2.99010 .702 \\
\hline । $\square$ । & । $\square$ । & $\begin{array}{llll}6 & 0.298 & 0.242\end{array}$ & 6.06950 .415 \\
\hline 101 & 101 & $7 \cdot-0.137-0.140$ & 6.76320 .454 \\
\hline 11 & 101 & $8-0.031 \quad 0.055$ & 6.80030 .558 \\
\hline
\end{tabular}

Fig. 5. Correlogram and partial Correlogram for $1^{\text {st }}$ differences of import crude oil price 
Long-run and short-run relationship between oil price and economic growth

Since the main focus is to assess how economic growth in the long-run responds to OP, GCF and LFPR, it has been conducted a cointegration test in line with the Johansen test to determine the cointegrating rank, i.e., the number of cointegrating vectors among the variables. The results in Table 3 conclude that all the series are non-stationary at a level. Consequently, oil price (OP), real gross domestic product (RGDP), gross capital formation (GCF) and labour force participation rate (LFPR) may be considered as $1^{\text {st }}$ order integrated variables. The findings reveal cointegration (long-run) relationship between oil price (OP), gross capital formation (GCF), labour force participation rate (LFPR) and real gross domestic product (RGDP) for Bangladesh.

The results of the Johansen maximal eigenvalue and trace tests have been reported in Table 4 and Table 5 . From the maximal Eigen value test in Table 4, it is seen that there is no cointegration relationship $(\mathrm{r}=0)$ has been rejected since the calculated $\lambda_{\max }$ is 44.830 which is greater than the critical value at the $5 \%$ significance level. The $\lambda_{\max }$ statistic has suggested that there are 2 cointegrating vectors at the 0.05 level. The $\lambda_{\text {trace }}$ test in Table 5 suggests 3 cointegrating vectors at the 0.05 level. Therefore, two cointegrating relationships exist among the variables in the economic growth model.

Table 6 presents the coefficients $(\beta)$ of the variables in the model. The diagnostic test supports the inclusion of trend in the long-run equation of economic growth. The trend interprets the impact of Bangladesh's developing process. The long run relationship by cointegration test shows that assuming fixed trend, GCF and LFPR, a 10 percent increase in the crude oil prices will cause the level of economic growth to decrease by 0.026 percent but it does not significantly affect the economic growth. Similarly, assuming other variables constant, a 10 percent increase in the GCF will cause the level of economic growth to significantly increase by 2.604 percent and likewise, assuming fixed trend, OP and GCF, a 10 percent increase in the LFPR will cause the level of economic growth to significantly increase by 17.252 percent.
The error correction model has been developed by taking two cointegrating equations Table 8 . The results from the error correction model have been reported in Table 7. It is found that the short-run impact of oil price on economic growth is negative and statistically significant. The first error correction term (ECM) for economic growth is statistically significant and negative. This implies that long-run equilibrium condition does not influence the short-run dynamics directly. The coefficient of $\operatorname{ECM}(1)$ suggests that if the selected variables have one cointegrating rank, the economic growth will converge towards its long-run equilibrium level in a fairly high speed after an oil price shock or a fluctuation of the LFPR. The coefficient of ECM (2) suggests that if the selected variables have two cointegrating ranks, the economic growth will converge towards its long-run equilibrium level in a very low speed after a fluctuation of the LFPR.

\section{Relationship between oil price and food security}

Granger causality test provides a chain relationship between oil price and global food security index. That is, lnGFSI and lnRGDP has bidirectional causality, so the variables are endogenous. On the other hand, lnCPI does Granger cause lnGFSI and lnOP does Granger cause $\operatorname{lnRGDP}$, so $\operatorname{lnCPI}$ and $\operatorname{lnOP}$ are exogenous variables (Table 9). It is not possible to model a direct causal relationship between oil price and food security, because Granger causality test has been indicated that lnGFSI has no causal relationship with lnOP. So, oil price does not directly impact food security, yet it remains possible to find existence of the relationship among them.

Table 10 has postulated the three stage least square estimates of simultaneous equations regression model. The $\mathrm{R}^{2}$ values indicate the high goodness of fit of the model to the data. The coefficient of lnOP indicates that $1 \%$ increase in import oil price decrease the real gross domestic product by $24 \%$. This $\operatorname{lnRGDP}$ has been used to estimate lnGFSI. Therefore the increase in import oil price has negative impact on global food security index. To sum up, the three stage least squares estimates of simultaneous equation model have revealed that oil prices have significant $(\mathrm{P}<0.05)$ negative impact on economic growth which in turn affects to gain food security in Bangladesh.

Table 3. Unit root test for $\operatorname{lnOP}, \ln R G D P, \operatorname{lnGCF}$ and $\operatorname{lnLFPR}$

\begin{tabular}{lllllllll}
\hline Variables & \multicolumn{3}{c}{ Augmented Dickey-Fuller Test } & \multicolumn{3}{c}{ Phillips-Perron Test } \\
\cline { 2 - 9 } & \multicolumn{3}{c}{ Level } & \multicolumn{2}{c}{ First Difference } & \multicolumn{2}{c}{ Level } & \multicolumn{2}{c}{ First Difference } \\
\cline { 2 - 9 } & Test Statistic & p-value & Test Statistic & p-value & Test Statistic & p-value & Test Statistic & p-value \\
\hline $\ln$ OP & -2.858 & 0.192 & $-4.665^{* * *}$ & 0.006 & -2.842 & 0.197 & $-4.672 * * *$ & 0.006 \\
lnRGDP & -1.269 & 0.870 & $-3.521^{*}$ & 0.062 & -0.262 & 0.987 & $-3.459 *$ & 0.068 \\
lnGCF & -2.985 & 0.156 & $-7.787 * * *$ & 0.000 & -3.075 & 0.134 & $-7.733 * * *$ & 0.000 \\
lnLFPR & -2.852 & 0.195 & $-3.498^{*}$ & 0.063 & -0.576 & 0.9713 & $-3.471 *$ & 0.067 \\
\hline
\end{tabular}

Note: $*$ denotes significant at $\mathrm{p}<0.1$ and $* * *$ denotes significant at $\mathrm{p}<0.01$. 
Table 4. Johansen cointegration test based on $\lambda_{\max }$

\begin{tabular}{|c|c|c|c|c|c|c|}
\hline \multicolumn{2}{|l|}{ No. of CE(s) } & \multirow[t]{2}{*}{ Eigen value } & \multirow{2}{*}{$\begin{array}{l}\text { Max-Eigen } \\
\text { Statistic }\end{array}$} & \multirow{2}{*}{$\begin{array}{l}\text { Critical } \\
\text { Value at } \\
0.05 \text { level }\end{array}$} & \multirow[t]{2}{*}{ p-value** } & \multirow[t]{2}{*}{ Decision } \\
\hline $\begin{array}{l}\text { Null hypothesis, } \\
\mathrm{H}_{0}\end{array}$ & $\begin{array}{l}\text { Alternative } \\
\text { hypothesis, } \mathrm{H}_{1}\end{array}$ & & & & & \\
\hline $\mathrm{r}=0$ & $r=1$ & 0.858 & 44.830 & 32.118 & 0.0009 & $\mathrm{H}_{0}$ reject \\
\hline$r \leq 1$ & $r=2$ & 0.793 & 36.278 & 25.823 & 0.0015 & $\mathrm{H}_{0}$ reject \\
\hline$r \leq 2$ & $r=3$ & 0.522 & 16.996 & 19.387 & 0.1076 & $\mathrm{H}_{0}$ accept \\
\hline$r \leq 3$ & $r=4$ & 0.397 & 11.625 & 12.518 & 0.0702 & $\mathrm{H}_{0}$ accept \\
\hline
\end{tabular}

Note: ** denotes MacKinnon-Haug-Michelis (1999) p-values.

Table 5. Johansen cointegration test based on $\lambda_{\text {trace }}$

\begin{tabular}{llllccc}
\hline No. of CE(s) & Eigen value & $\begin{array}{c}\text { Trace } \\
\text { Statistic }\end{array}$ & $\begin{array}{c}\text { Critical } \\
\text { Value at } \\
\text { Null hypothesis, } \\
\mathrm{H}_{0}\end{array}$ & $\begin{array}{c}\text { Alternative } \\
\text { hypothesis, } \mathrm{H}_{1}\end{array}$ & \multicolumn{5}{c}{ p-value** } & Decision \\
\cline { 1 - 5 } $\mathrm{r}=0$ & $\mathrm{r} \geq 1$ & 0.858 & 109.729 & 63.87610 & 0.0000 & $\mathrm{H}_{0}$ reject \\
$\mathrm{r} \leq 1$ & $\mathrm{r} \geq 2$ & 0.793 & 64.899 & 42.91525 & 0.0001 & $\mathrm{H}_{0}$ reject \\
$\mathrm{r} \leq 2$ & $\mathrm{r} \geq 3$ & 0.522 & 28.621 & 25.87211 & 0.0222 & $\mathrm{H}_{0}$ reject \\
$\mathrm{r} \leq 3$ & $\mathrm{r}=4$ & 0.397 & 11.625 & 12.51798 & 0.0702 & $\mathrm{H}_{0}$ accept \\
\hline
\end{tabular}

Note: ** denotes MacKinnon-Haug-Michelis (1999) p-values.

Table 6. Long run relationship by cointegration test

\begin{tabular}{ccccc}
\hline Variables & Coefficient & Std. Error & t-Statistic & p-value \\
\hline Constant & 11.16382 & 0.981668 & 11.37230 & 0.0000 \\
Trend & 0.036589 & 0.003449 & 10.60886 & 0.0000 \\
lnOP & -0.002581 & 0.002883 & -0.895021 & 0.3820 \\
lnGCF & 0.260444 & 0.041368 & 6.295771 & 0.0000 \\
lnLFPR & 1.725239 & 0.054607 & 31.59373 & 0.0000 \\
\hline
\end{tabular}

Table 7. Estimates of short run error correction model

\begin{tabular}{cccc}
\hline Variables & Coefficients & Standard Error & t-statistic \\
\hline ECM(1) & -0.808278 & 0.26140 & $-3.09210^{* *}$ \\
ECM $(2)$ & -0.009112 & 0.00556 & -1.63786 \\
$\Delta \ln R G D P_{t-1}$ & 0.623566 & 0.17319 & $3.60051^{* *}$ \\
$\Delta \ln R G D P_{t-2}$ & 0.515220 & 0.24618 & $2.09289^{*}$ \\
$\Delta \ln O P_{t-1}$ & -0.000402 & 0.00468 & -0.08603 \\
$\Delta \ln O P_{t-2}$ & -0.010176 & 0.00485 & $-2.09600^{*}$ \\
$\Delta \ln G C F_{t-1}$ & 0.121481 & 0.09309 & 1.30499 \\
$\Delta \ln G C F_{t-2}$ & 0.135874 & 0.07236 & $1.87776^{*}$ \\
$\Delta \ln L F P R_{t-1}$ & -1.463549 & 0.73059 & $-2.00325^{*}$ \\
$\Delta \ln L F P R_{t-2}$ & -1.210873 & 1.01164 & -1.19694 \\
Constant & -0.035050 & 0.01802 & -1.94556 \\
\hline
\end{tabular}

Note: $\triangle \ln R G D P$ is dependent variable. * and ** indicates significant at 5-percent and 10 percent levels respectively comparing critical t-statistics from standard t-table. 
Table 8. Equation of Error Correction Term

\begin{tabular}{ccc}
\hline Cointegrating Eq: & ECM $(1)$ & ECM $(2)$ \\
\hline $\ln R G D P_{t-1}$ & 1.000000 & 0.000000 \\
$\ln O P_{t-1}$ & 0.000000 & 1.000000 \\
$\ln G C F_{t-1}$ & 0.293515 & 8.826897 \\
& $(0.06047)$ & {$[3.09472)$} \\
& {$[4.85375]$} & $7.2589224]$ \\
$\ln$ FPR $_{t-1}$ & -1.687434 & $(3.39530)$ \\
& $(0.06635)$ & {$[2.13794]$} \\
TREND & {$[-25.4342]$} & -0.822257 \\
& -0.082844 & $(0.25731)$ \\
Constant & $(0.00503)$ & {$[-3.19565]$} \\
\end{tabular}

Table 9. Granger causality test

\begin{tabular}{cccc}
\hline Null Hypothesis & F-Statistic & P-value & Decision \\
\hline lnCPI does not Granger Cause lnOP & 1.95229 & 0.2349 & Null accept at 10\% level \\
lnOP does not Granger Cause lnCPI & 4.70847 & 0.0958 & Null reject at $10 \%$ level \\
lnGFSI does not Granger Cause lnOP & 0.15205 & 0.7165 & Null accept at $10 \%$ level \\
lnOP does not Granger Cause lnGFSI & 2.67932 & 0.1770 & Null accept at $10 \%$ level \\
lnRGDP does not Granger Cause lnOP & 1.41440 & 0.3001 & Null accept at $10 \%$ level \\
lnOP does not Granger Cause lnRGDP & 5.26514 & 0.0834 & Null reject at $10 \%$ level \\
lnGFSI does not Granger Cause lnCPI & 0.22996 & 0.6566 & Null accept at $10 \%$ level \\
lnCPI does not Granger Cause lnGFSI & 7.46757 & 0.0523 & Null reject at $10 \%$ level \\
lnRGDP does not Granger Cause lnCPI & 0.22391 & 0.6607 & Null accept at $10 \%$ level \\
lnCPI does not Granger Cause lnRGDP & 0.98572 & 0.3770 & Null accept at $10 \%$ level \\
lnRGDP does not Granger Cause lnGFSI & 5.79648 & 0.0737 & Null reject at $10 \%$ level \\
lnGFSI does not Granger Cause lnRGDP & 17.1752 & 0.0143 & Null reject at 5\% level \\
\hline
\end{tabular}

Table 10. Estimated values of coefficients and related statistics of three stage least squares (3SLS) regression

\begin{tabular}{lllllll}
\hline & & Coefficient & Standard Error & z-Statistic & p-value & $\mathrm{R}^{2}$ \\
\hline \multirow{2}{*}{$\ln$ RGDP } & lnGFSI & 3.293068 & 0.8323286 & 3.96 & 0.000 & 0.6429 \\
& lnOP & -.2400725 & 0.1096353 & -2.19 & 0.029 & \\
& Constant & 15.58743 & 2.272004 & 6.86 & 0.000 & 0.7203 \\
\multirow{3}{*}{$\ln$ GFSI } & lnRGDP & 0.1004032 & 0.0270158 & 3.72 & 0.000 & 0.172 \\
& lnCPI & 0.1994192 & 0.1461075 & 1.36 & & \\
& Constant & (omitted) & & & & \\
\hline
\end{tabular}

\section{Conclusions and Policy Recommendations}

The history of Bangladesh in the open market is not too long but at present time, the high dependency of the food system on fuel and transport make the agri based economy more vulnerable. Therefore, our study sheds light on oil price volatility and the impact of oil price changes on economic growth and food security in Bangladesh. Although, there is a growing body of literature which focuses on the oil price volatility and the impact of oil price changes on the growth of the economy, but comparatively little is known about the impact of oil price changes on food security, indeed the existing literatures on oil price and food prices mainly point out the interdependencies. To mitigate this gap, the present paper uses relatively innovative approach and yearly data of macroeconomic variables as well as global food security index which focus on Bangladesh.
We use GARCH model to identify the oil price unpredictability. It is evident from the literature that oil price volatility has a negative impact on economic growth and food security. The findings of unit root test and correlogram test reveal that time series international oil price and import oil price are first differenced stationary. The GARCH $(2,1)$ model asserts that volatility was high in the previous period and it has been continued to be lower in the current period. In addition, the long-run and short-run dynamics of the relationship between economic growth and oil price have been identified by co-integration test and error correction model respectively. There is an evidence of long-run relationship among OP, GCF, LFPR and RGDP. In other words, the result shows an increase in oil price has a negative impact on economic growth in both short and 
long-run. The three-stage least squares regression model has been applied to show the impact of oil price changes on food security which is followed by Hausman's specification error test. The findings reveal that an increase in oil price declines the economic growth and food security simultaneously. It is thus palpable that Bangladesh's economy is vulnerable due to oil price volatility. These results are expected to help the policymakers for sustainable economic development and cope up with the external shocks associated with increasing oil prices.

A number of recommendations regarding to cope up with the oil price volatility in our study are based on (i) Research findings and (ii) Economists' suggestions. On the basis of research findings the recommendations are: Since volatility exists in international oil price and import oil price, they are very much responsive so government policy should be quick receptive in relation to international oil market to create consistent oil market in Bangladesh. As the oil price changes have a negative impact on economic growth and food security in Bangladesh. So it is not a good sign for the economy. Since Bangladesh is an importer of crude oil, policymakers should design the optimal policy mix.

On the basis of the expert opinion survey a number of policy implications emanate, these are: First, updated information and strong monitoring authority about the oil demand and supply by a strong monitoring authority should be ensured in domestic market; Second, government has to determine the ceiling of profit margin of the oil distributors and also ensure financial ability to speculate oil as a short-term solution during the period of international crisis; Third, geopolitical negotiation should be improved and financial capability of the country also should be ensured so that the oil can be subsidized during economic instability throughout the world; Fourth, keeping in mind the interest of the farmers and the consumers, government intervention in the oil market should be such that the overall economic growth and the food security for the poor would never compromise; And finally, Public Private Partnership (PPP) should be increased in energy for sustainable economic growth and food security.

\section{Acknowledgements}

This article is prepared from the first authors' MS thesis work since the study is mainly based on secondary data there was no research grant to mention. The authors are highly grateful to the participants because of their participation during interview which helps the authors to make policy guidelines.

\section{References}

Akram, M. 2011. Do Crude Oil Price Changes Affect Economic Growth of India, Pakistan and Bangladesh? : A Multivariate Time Series Analysis. MS Thesis, School of Technology and Business Studies, Economics, Dalarna University.
Bakhat, M. and Wurzburg, K. 2013. Price Relationships of Crude Oil and Food Commodities, Working Paper, Alcoa Foundation.

Bangladesh Economic Review 2015. Economic Adviser's Wing, Financial Division,Ministry of Finance, Government of the People's Republic of Bangladesh, Dhaka.

Bollerslev, T. 1986. Generalized Autoregressive Conditional Heteroscedasticity. Journal of Econometrics 31: 307-326. https://doi.org/10.1016/0304-4076(86)90063-1

Burbidge, J. and Harrison, A. 1984. Testing for the effects of oil-price rises using vector autoregressions. International Economics Review 25: 459-484. https://doi.org/10.2307/2526209

Cunado, J. and Gracia, F.P. 2005. Oil Prices, Economic Activity and Inflation: Evidence for Some Asian Countries. The Quarterly Review of Economics and Finance 45 (1): 65-83. https://doi.org/10.1016/j.qref.2004.02.003

Ciaian, P. and Kancs, d'A 2011. Interdependencies in the energybioenergy-food price systems: A cointegration analysis. Resource and Energy Economics 33 p. 326-348.

Dillon, B.M. and Barrett, C.B. 2015. Global Oil Prices and Local Food Prices: Evidence from East Africa. Amer. J. Agr. Econ 98 (1): 154-171. https://doi.org/10.1093/ajae/aav040

Ferderer, J.P. 1996. Oil price volatility and the macroeconomy. Journal of Macroeconomics18 (1): 1-26. https://doi.org/10.1016/ S0164-0704(96)80001-2

Food and Agriculture Organization of the United Nations 2016. Available at http://faostat.fao.org/beta/en/\#country/16.

Gisser, M. and Goodwin, T. 1986. Crude oil and the macroeconomy: tests of some popular notions. Journal of Money, Credit and Banking 18: 95-103. https://doi.org/10.2307/1992323

Hamilton, J. 2003. What is an oil shock? Journal of Econometrics 113: 363-398. https://doi.org/10.1016/S0304-4076(02)00207-5

Hao, N., Colson, G., Karali, B. and Wetzstein, M. 2013. Food before Biodiesel Fuel? Selected Paper prepared for presentation at the Southern Agricultural Economics Association (SAEA) Annual Meeting, Orlando, Florida, 3-5 February 2013.

InflationData.com. 2015. Historical Crude Oil Prices Table, Available at http://inflationdata.com/Inflation/Inflation_Rate/Historicalᄀ ᄀ-_Oil_Prices_Table.asp.

Mgbame, C.O., Donwa, P.A. and Onyeokweni, O.V. (2015). "Impact of Oil Price Volatility on Economic Growth: Conceptual Perspective." International Journal of Multidisciplinary Research and Development. Volume: 2, Issue: 9, pp. 80-85.

Johansen, S. and Juselius, K. 1990. Maximum Likelihood Estimation and Inference on Cointegration with Application to Demand for Money. Oxford Bulletin of Economics and Statistics 52: 169-210. https://doi.org/10.1111/j.14680084.1990.mp52002003.x

Lee, K., Ni, S. and Ratti, R. 1995. Oil shocks and the macroeconomy: the role of price variability. Energy Journal 16: 39-56. https://doi.org/10.5547/ISSN0195-6574-EJ-Vol16-No4-2

Mork, K. 1989). Oil shocks and the macroeconomy when prices go up and down: an extension of Hamilton's results. Journal of Political Economy 97: 740-744. https://doi.org/ 10.1086/261625

Mork, K.A. and Olsen, O. 1994. Macroeconomic responses to oil price increases and decreases in seven OECD countries. Energy Journal 15 (4): 19-35.

Rautava, J. 2004. The Role of Oil Prices and the Real Exchange Rate in Russia's economy A Cointegration Approach. Journal of Comparative Economics 32 (2): 315-327. https://doi.org/ 10.1016/j.jce.2004.02.006

Romer, D. (2006). Advanced Macroeconomics, McGraw-Hill//rwin, NY, 143.

Srithar, P.D., Bairavi, N. and Mariselvam, G. 2015. Oil Price Volatility and its Impact on the selected Economic Indicators in India. International Academic Research Journal of Economics and Finance 3 (4): 10-16.

Torero, M. 2014. Food security brings economic growth-not the other way around. IFPRI BLOG, Available at https://www.ifpri.org/blog/food-security-brings-economicgrowth-not-other-way-around.

World Bank 2016. World Development Indicators, Available at http://data. worldbank.org/country/bangladesh?view=chart. 


\section{Appendix}

\section{GARCH $(2,1)$ Model}

Dependent variable: INPRICE

Method: ML-ARCH (Marquardt)- Normal distribution

Date: 12/25/16 Time: 22:23

Sample: 125

Included observations: 25

Convergence achieved after 27 iterations

Presample variance: backcast (parameter $=0.7$ )

$\mathrm{GARCH}=\mathrm{C}(1)+\mathrm{C}(2) * \operatorname{RESID}(-1)^{\Lambda} 2+\mathrm{C}(3)^{\mathrm{A}}$

\begin{tabular}{ccccc}
\hline Variable & Coefficient & Std. Error & z-Statistic & Prob. \\
\hline \multicolumn{4}{c}{ Variance Equation } \\
\hline RESID $(-1)^{\wedge} 2$ & $5.00 \mathrm{E}+08$ & $4.90 \mathrm{E}+08$ & 1.020328 & 0.3076 \\
RESID $(-2)^{\wedge} 2$ & 1.044797 & 1.900418 & 0.549772 & 0.5825 \\
GARCH $(-1)$ & 0.852071 & 2.127713 & 0.400463 & 0.6888 \\
\hline R-squared & -0.993013 & 0.094047 & -10.55874 & 0.0000 \\
Adjusted R-squared & -1.4229 .8 & Mean dependent var & 20643.67 \\
S.E. of regression & -1.325992 & S.D. dependent var & 17662.93 \\
Sum squared resid & 26938.10 & Akaike info criterion & 22.76377 \\
Log likelihood & $1.81 \mathrm{E}+10$ & Schwarz criterion & 22.95879 \\
Durbin-Watson stat & -280.5472 & Hannan-Quinn criter & 22.81786 \\
\hline
\end{tabular}

Dependent variable: INPRICE

Method: ML-ARCH (Marquardt)- Normal distribution

Date: 12/25/16 Time: 22:35

Sample: 125

Included observations: 25

Convergence achieved after 18 iterations

Presample variance: backcast (parameter $=0.7$ )

$\mathrm{GARCH}=\mathrm{C}(1)+\mathrm{C}(2) * \operatorname{RESID}(-1)^{\Lambda} 2+\mathrm{C}(3) * \operatorname{RESID}(-2)^{\Lambda} 2+\mathrm{C}(4) * \operatorname{GARCH}(-1)$

\begin{tabular}{ccccc}
\hline Variable & Coefficient & Std. Error & z-Statistic & Prob. \\
\hline \multicolumn{4}{c}{ Variance Equation } \\
\hline RESID $(-1)^{\wedge} 2$ & $7.71 \mathrm{E}+08$ & $6.77 \mathrm{E}+08$ & 1.138961 & 0.2547 \\
RESID $(-2)^{\wedge} 2$ & 0.978923 & 2.859556 & 0.342334 & 0.7321 \\
GARCH $(-1)$ & 1.085571 & 3.813380 & 0.284674 & 0.7759 \\
\hline R-squared & -0.990810 & 0.056510 & -17.53346 & 0.0000 \\
Adjusted R-squared & -1.320672 & \multicolumn{2}{c}{ Mean dependent var } & 25244.97 \\
S.E. of regression & -1.227846 & S.D. dependent var & 22420.32 \\
Sum squared resid & 33464.49 & Akaike info criterion & 23.14643 \\
Log likelihood & $2.80 \mathrm{E}+10$ & Schwarz criterion & 23.34145 \\
Durbin-Watson stat & -285.3303 & \multicolumn{2}{c}{ Hannan-Quinn criter } & 23.20052 \\
\hline
\end{tabular}

Note: 'INPRICE' indicates crude international oil price and 'IMPRICE' indicates crude import oil price. 